\title{
STRATEGIES FOR USING PROFIT AND CASH FLOW STATEMENTS IN ASSESSING THE FINANCIAL PERFORMANCE OF PRIVATE BANK COMPANIES ON THE INDONESIA STOCK EXCHANGE
}

\author{
Maulana Majied Sumatrani Saragih \\ Universitas Darma Agung, Pascasarjana Universitas Darma Agung, Jalan DR. TD Pardede \\ No 21, Medan, 20153, Sumatera Utara. \\ Coresponding author: maulanamajied494@gmail.com
}

\begin{abstract}
ABSTRACK
This study aims to find out how the Strategy for Using Profit and Cash Flow Statements on the Financial Performance of Indonesian Private Banks Listed on the Indonesia Stock Exchange. The research method used is quantitative data method. While the data used is secondary data. The data analysis method in this study uses multiple linear regression analysis to obtain a comprehensive picture of the effect of the Profit Usage variable on Financial Performance by using the SPSS 25 for Windows program. To find out whether there is a significant effect of the independent variable on the dependent variable, a simple linear regression model is used. The results of hypothesis testing using multiple regression analysis and test show that: The use of profit (X1) has a positive and significant effect on Financial Performance (Y). In other words, it means, the use of profit has a positive and significant effect on financial performance. Cash Flow (X2) has no effect on Financial Performance (Y). In other words, it means, Cash Flow has no positive and significant effect on Financial Performance. Use of Profit (X1), Cash Flow Variable (X2), have a significant effect simultaneously (simultaneously) on the Financial Performance Variable (Y).
\end{abstract}

Keywords: Use of Profit, Cash Flow and Financial Performance.

\section{INTRUDUCTION}

The main purpose a company is to get profits that are compiled in an income statement with the aim in describing the results in the company's operations in a certain period. In other words, the income statement describes the success or failure of the company's operations in an effort to achieve goals. The company's operating results are measured by comparing the company's revenue with costs.

Companies must observe and analyze the company's performance in order to survive, one in which is to perform a performance analysis from the financial side of the financial statements. One way to measure the level in company performance is to use a cash flow statement. Performance appraisal in a company can be done by analyzing two aspects, namely financial performance and non-financial performance. Financial performance can be seen through financial report data, while non-financial performance can be seen through nonfinancial aspects including marketing aspects, technology aspects and management aspects. Financial reporting is a financial report that is supplemented with other information related, 
either directly or indirectly, to the information provided by the financial accounting system, such as information about company resources, earnings, current costs, information about company prospects which are an integral part in the company's financial statements. the purpose in meeting an adequate level disclosure.

As we know that finance is a very important field in a company. Both large and smallscale companies, profit motives and non-profit motives will have great attention in the financial sector, especially in the development of an increasingly advanced business world, causing competition between companies to be even tighter, thus requiring companies to be able to make the company more efficient in operating so that it can continuously improve its competitive ability for the survival of the company.

Profit is also used as a tool to measure the performance of company management over a certain period. Profit is generally the concern of certain parties, especially in assessing the performance of management accountability in managing the resources entrusted to them, and can be used to estimate future prospects.

Table 1.1

Indonesian Private Bank Net Profit Report on IDX

(Year 2018 - 2020)

(In millions of rupiah)

\begin{tabular}{|c|c|c|c|c|}
\hline Code & $\underline{\text { Private Bank }}$ & $\begin{array}{c}\text { Profit } \\
2018\end{array}$ & $\begin{array}{c}\text { Profit } \\
2019\end{array}$ & $\begin{array}{c}\text { Profit } \\
2020\end{array}$ \\
\hline BABP & Bank MNC Internasional, Tbk & 9.846 & 675.859 & 43.084 \\
\hline BBCA & Bank Central Asia, Tbk & 27.404 & 24.075 & 26.766 \\
\hline BBKP & Bank Bukopin, Tbk & 1.091 & 174.934 & 379 \\
\hline BBMD & Bank Mestika Dharma, Tbk & 477.941 & 2.460 .865 & 265.862 \\
\hline BDMN & Bank Danamon, Tbk & 2.834 & 3.708 & 4.107 \\
\hline BNBA & Bank Bumi Arta, Tbk & 77.121 & 85.912 & 155.025 \\
\hline BNGA & Bank CIMB Niaga, Tbk & 5.528 & 2.977 & 3.482 \\
\hline BNII & Bank Maybank Indonesia, Tbk & 3.529 & 1.892 & 2.701 \\
\hline BNLI & Bank Permata, Tbk & 333.783 & 735.333 & 23.373 \\
\hline BSIM & Bank Sinarmas, Tbk & 287.039 & 234.947 & 14.094 \\
\hline
\end{tabular}

Source: www.idx.co.id

The statement cash flows in a company is presented to provide information about cash such as management, creditors, and investors, especially regarding the company's cash in a certain period. The cash flow statement as an integral part of the company's financial statements presents data on the company's cash condition from its operating, investing and financing activities. Several previous studies stated that cash flow statements contain useful information for investors. One of the reasons for conducting an analysis of the cash flow 
statement is to assess the company's financial performance. Where is the performance assessment to determine the level of efficiency and effectiveness of the organization in achieving the goals that have been set.

For internal companies by analyzing the cash flow statement, the management will find out whether the policies implemented are going well in terms in obtaining and using the cash in a certain period. As for external parties in the company, the information in this cash flow statement will help investors, creditors, and other parties in assessing various aspects in the company's financial position.

Table 1.1

Indonesian Private Bank Cash Flow Statement on IDX

(Year 2018 - 2020)

(In millions of rupiah)

\begin{tabular}{|c|c|c|c|c|}
\hline Code & $\underline{\text { Private Bank }}$ & $\begin{array}{c}\text { Cash Flow } \\
2018\end{array}$ & $\begin{array}{c}\text { Cash Flow } \\
2019\end{array}$ & $\begin{array}{c}\text { Cash Flow } \\
2020\end{array}$ \\
\hline BABP & Bank MNC Internasional, Tbk & 3.094 & 2.344 & 3.412 \\
\hline $\mathrm{BBCA}$ & Bank Central Asia, Tbk & 100.838 & 213.039 & 220.939 \\
\hline BBKP & Bank Bukopin, Tbk & 16.022 & 15.215 & 14.938 \\
\hline BBMD & Bank Mestika Dharma, Tbk & 295.054 & 13.009 & 4.049 \\
\hline BDMN & Bank Danamon, Tbk & 15.032 & 12.042 & 14.049 \\
\hline BNBA & Bank Bumi Arta, Tbk & 1.555 & 2.635 & 1.635 \\
\hline BNGA & Bank CIMB Niaga, Tbk & 3.949 & 12.049 & 11.847 \\
\hline BNII & Bank Maybank Indonesia, Tbk & 18.746 & 17.926 & 15.098 \\
\hline BNLI & Bank Permata, Tbk & 25.047 & 24.946 & 20.536 \\
\hline BSIM & Bank Sinarmas, Tbk & 253.746 & 29.424 & 28.747 \\
\hline
\end{tabular}

Source: $\underline{w w w . i d x . c o . i d}$

Cash Flow Statement is a report that contains information about cash funds that enter and leave a company in one period certain accounting. In the statement in cash flows are distinguished based on its activities. There are three main activities reported in the statement in cash flowsa company, namely cash flow from operational activities, cash flow from activitiesinvestments and cash flows from financing activities.

\section{LITERATURE REVIEWS}

\subsection{Financial Management}

Fahmi (2015: 2), financial management is a combination of science and art that discusses, examines and analyzes how a financial manager uses all company resources to seek funds, manage funds and share funds with the aim of being able to provide profit or prosperity for the community. shareholders and business sustainability sustainability for 
the company. Meanwhile, according to Horne and Wachowicz (2012: 2), financial management is related to the acquisition of assets, funding, and asset management based on several general objectives.

\subsection{Financial Performance}

Financial performance is the result or achievement that has been achieved by the company's management in managing the company's assets effectively during a certain period. Financial performance is needed by companies to know and evaluate the company's success rate based on financial activities that have been carried out by Rudianto (2013: 189). According to Fahmi (2017:2) financial performance is an analysis carried out to find out the extent to which the company has implemented the rules that have been set regarding the use in finance appropriately and correctly.

Financial performance can be assessed with several analytical tools. Jumingan in Agung (2012:6) explains that based on the analysis technique, it is divided into 8 types, namely: 1) Comparative analysis in financial statements, is an analytical technique by comparing financial statements in two or more periods by showing changes, both in total (absolute) and in percentage. (relatively). 2) Trend Analysis (position tendency), is an analytical technique to determine the tendency of the financial condition to show an increase or decrease. 3) Analysis of Percentage per Component (common size), is an analytical technique to determine the percentage in investment in each asset to the total or total assets and debts. 4) Analysis of Sources and Uses of Working Capital, is an analytical technique to determine the amount of sources and uses of working capital through two periods in time being compared. 5) Analysis of Cash Sources and Uses, is an analytical technique to determine the condition of cash along with the causes of changes in cash in a certain period of time.

Munawir (2012: 31) the factors that affect financial performance are: 1) Liquidity, which is able to show the ability of a company to meet its financial obligations that must be fulfilled immediately or the company's ability to meet its financial obligations when billed. 2) Solvency, which is able to show the company's ability to meet its financial obligations if the company is liquidated both short-term and long-term finance. 3) Profitability or Profitability, which shows the company's ability to generate profits during a certain period. 4) Economic Stability, which shows the company's ability to carry out its business in a stable manner, which is measured by considering the company's ability to pay its debts and pay dividends regularly without experiencing obstacles or financial crises.

\subsection{Use of Profit}

L.M. Samryn (2012:429), states that the understanding in profit is as follows: "Profit is an internal source of funds that can be obtained from normal company activities that do not require extra costs for storage and use". Meanwhile, according to Wild and Subramanyam (2014:25), states that the meaning of profit is as follows: "Earnings or net income indicates the company's profitability. Earnings reflect returns to equity holders for the period, while items in the report detail how profits are earned".

Earnings management is an accounting characteristic that contains many estimates, judgments and accrual properties that open up opportunities to be able to regulate (Sofyan Harahap, 2011). Earnings management (earnings management) is done by playing with the accrual component in the financial statements or manipulation, because accruals are 
components that are easy to manipulate according to the wishes or goals of the person who records the financial statements. Earnings management is not a detrimental thing as long as it is carried out in corridors of opportunity, earnings management is not always defined by the process of manipulating financial statements because there are several methods that can be used and not as a prohibition (Kusumawardhani, 2012).

\subsection{Cash Flow}

According to the Statement of Accounting Standards Number 2 of 2009, cash flows are the inflows and outflows of cash and cash equivalents (Indonesian Accounting Association, 2013). Understanding cash inflows and cash outflows are cash inflows (cash inflows) are sources from which cash is obtained, while cash outflows are cash needs for payments (Martono and Harjito, 2012). According to Rudianto (2012: 194) defines a cash flow statement as follows: "The cash flow report is a report on the company's cash receipts and disbursements activities during a certain period, along with an explanation of the sources of cash receipts and disbursements.

The amount of cash flow from operating activities is an indicator that determines whether the company's operations can generate sufficient cash flow to repay loans, maintain the company's operating capabilities, pay dividends and make new investments without relying on external funding sources (Indonesian Accounting Association, 2013).

\section{RESEARCH METHODS}

Methods of data collection by using the method of literature and documentation methods. The library method, namely by obtaining data from reading and studying written sources or references related to the problems discussed. Documentation method, namely by obtaining data from documents in the form of annual financial reports obtained from www.idx.co.id. The secondary data used in this study is the financial statements of private banks listed on the Indonesia Stock Exchange (2018-2020 period).

This study uses multiple regression method, to analyze the impact of the independent variable on the dependent. Multiple regression analysis was chosen because there is a significant influence or not the use of profit and cash flow independent variables on financial performance. The t-test was used to partially test the effect of the independent variable on the dependent variable, namely the effect of each independent variable consisting of the use of earnings and cash flow on financial performance. The F statistical test is basically to test whether the variable between the dependent variable and the independent variable is significant.

\section{DISCUSSION RESULT}

\subsection{Normality test}

Normality test aims to test whether in the regression model, the confounding or residual variables have a normal distribution (Ghozali, 2016:154). Testing the normality of the data can be done using two methods, graphs and statistics. Normality test using one sample test Kolmogorov Smirnov Test. 
Table 4.1. Uji One Sample Kolmogorov Smirnov Test One-Sample Kolmogorov-Smirnov Test

\begin{tabular}{|c|c|c|c|}
\hline & & & $\begin{array}{c}\text { Unstandardized } \\
\text { Residual }\end{array}$ \\
\hline \multicolumn{3}{|l|}{$\mathrm{N}$} & 30 \\
\hline \multirow[t]{3}{*}{ Normal Parameters } & Mean & & .0000002 \\
\hline & Std. Deviation & & 972573032.4870 \\
\hline & & & 6510 \\
\hline \multirow[t]{3}{*}{ Most Extreme Differences } & Absolute & & .135 \\
\hline & Positive & & .135 \\
\hline & Negative & & -.105 \\
\hline Test Statistic & & & .135 \\
\hline Asymp. Sig. (2-tailed) & & & $.169^{\circ}$ \\
\hline \multirow[t]{3}{*}{ Monte Carlo Sig. (2-tailed) } & Sig. & & $.633^{\circ}$ \\
\hline & \multirow[t]{2}{*}{$99 \%$ Confidence Interval } & Lower Bound & .407 \\
\hline & & Upper Bound & .860 \\
\hline
\end{tabular}

a. Test distribution is Normal.

Source: Data processed by SPSS 25 (2021)

It can be seen that the significance value (Monte Carlo Sig.) of all variables is 0.633 . If the significance is more than 0.05 , then the residual value is normal, so it can be concluded that all variables are normally distributed.

\subsection{Heteroscedasticity Test}

The heteroscedasticity test aims to test whether from the regression model there is an inequality of variance from the residuals of one observation to another observation. A good regression model is one with homoscedasticity or no heteroscedasticity.

The results of data processing using SPSS 25.00 show the results in the following table:

Table 4.2. Glejser Test Results Coefficients $^{\mathrm{a}}$

\begin{tabular}{|c|c|c|c|c|c|c|c|c|}
\hline \multicolumn{9}{|c|}{ Coefficients $^{a}$} \\
\hline \multirow{2}{*}{\multicolumn{2}{|c|}{ Model }} & \multicolumn{2}{|c|}{ Unstandardized Coefficients } & \multirow{2}{*}{$\begin{array}{c}\text { Standardized } \\
\text { Coefficients } \\
\text { Beta }\end{array}$} & \multirow[b]{2}{*}{$\mathrm{t}$} & \multirow[b]{2}{*}{ Sig. } & \multicolumn{2}{|c|}{$\begin{array}{c}\text { Collinearity } \\
\text { Statistics }\end{array}$} \\
\hline & & $\mathrm{B}$ & Std. Error & & & & Tolerance & VIF \\
\hline \multirow[t]{3}{*}{1} & (Constant) & 411803998.681 & 233708048.461 & & 1.762 & .089 & & \\
\hline & Penggunaan_Laba_X1 & .086 & .060 & .285 & 1.427 & .165 & .849 & 1.178 \\
\hline & Arus_Kas_X2 & -.009 & .090 & -.019 & -.097 & .923 & .849 & 1.178 \\
\hline
\end{tabular}

a. Dependent Variable: Abs_RES

Source: Data processed by SPSS 25 (2021)

Table 4.2 shows the significance value of the Profit Use variable (X1) of 0.165 , the significance value of the cash flow variable (X2) of 0.923 where the value of this variable is greater than 0.05 so it can be concluded that there are no symptoms of heteroscedasticity. 


\subsection{Autocorrelation Test}

Autocorrelation test aims to test whether in the linear regression model there is a correlation between the confounding error in period $t$ and the confounding error in period $t-1$ (previous.

\begin{tabular}{|c|c|c|c|c|c|}
\hline \multicolumn{6}{|c|}{$\begin{array}{l}\text { Table 4.3. Autocorrelation Test } \\
\text { Model Summary }\end{array}$} \\
\hline Model & $\mathrm{R}$ & R Square & Adjusted R Square & $\begin{array}{l}\text { Std. Error of the } \\
\text { Estimate }\end{array}$ & Durbin-Watson \\
\hline 1 & $.543^{\mathrm{a}}$ & .295 & .243 & 1007950814.53544 & 1.827 \\
\hline \multirow{2}{*}{\multicolumn{6}{|c|}{ a. Predictors: (Constant), Arus_Kas_X2, Penggunaan_Laba_X1 }} \\
\hline & & & & & \\
\hline \multicolumn{6}{|c|}{ Source: Data processed by SPSS $2 \overline{5}$ (2021) } \\
\hline
\end{tabular}

From table 4.3 above With the table value at a significance level of $5 \%$, the number of samples is $30(\mathrm{n})$ and the number of independent variables is $2(\mathrm{k}=2)$, then the DurbinWatson table will get the upper limit value (du) 1.566 and the lower limit (dl) 1,283. because the DW value of 1.827 is greater than the upper limit (du) of 1.566 and less than $4-1.566$ (4$\mathrm{du})$, it can be concluded that there is no autocorrelation in this regression model, or the calculation can be concluded that the DW value lies in the test area.

\subsection{Pengujian Regresi Linier Berganda}

Pengujian regresi linear Sederhana menjelaskan besarnya peranan variabel Tingkat Penggunaan Laba (X1), Variabel Arus Kas (X2) terhadap variabel Tingkat Kinerja Keuangan (Y). Analisis data dalam penelitian ini menggunakan analisis regresi linier sederhana dengan menggunakan SPSS 25.0 for windows. Analisis masing-masing variabel dijelaskan dalam uraian berikut :

Table 4.4. Multiple Linear Regression Results Coefficients $^{a}$

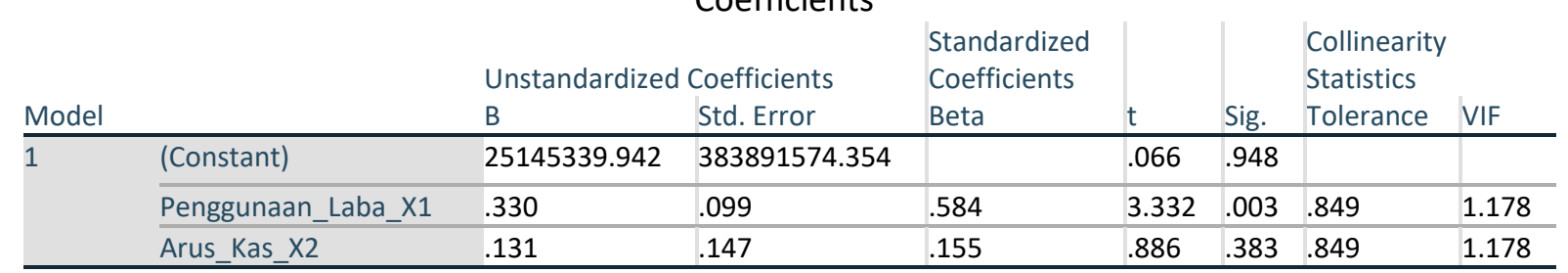

a. Dependent Variable: Kinerja_Keuangan_Y

Source: Data processed by SPSS $2 \overline{5}$ (2021)

Based on these results, the simple linear regression equation that describes the simple linear regression equation above is as follows: Based on these results, a simple linear regression equation which has the formulation: $\mathrm{Y}=\mathrm{a}+\mathrm{bX} 1+\mathrm{bX} 2$, so that the equation: $\mathrm{Y}=$ $25.942+0.330 \mathrm{X}+0.131 \mathrm{X}$

\subsection{Coefficient Determination $\left(\mathbf{R}^{2}\right)$}

The coefficient of determination is used to see how much the independent variable contributes to the dependent variable. The greater the value of the coefficient of determination, the better the ability of variable $\mathrm{X}$ to explain Variable $\mathrm{Y}$. If the determination 
(R2) is greater (closer to 1), it can be said that the influence of variable $\mathrm{X}$ is large on Financial Performance (Y).

This is because the adjusted $\mathrm{R}$ square value is not susceptible to the addition of independent variables. The value of the coefficient of determination can be seen in Table 4.5 below:

\begin{tabular}{|c|c|c|c|c|c|}
\hline \multirow[b]{2}{*}{ Model } & \multicolumn{5}{|c|}{$\begin{array}{l}\text { Table 4.5. Coefficient Determination } \\
\text { Model Summary }{ }^{b}\end{array}$} \\
\hline & $\mathrm{R}$ & R Square & Adjusted R Square & $\begin{array}{l}\text { Std. Error of the } \\
\text { Estimate }\end{array}$ & Durbin-Watson \\
\hline 1 & $.543^{a}$ & .295 & .243 & 1007950814.53544 & 1.827 \\
\hline \multicolumn{6}{|c|}{$\begin{array}{l}\text { a. Predictors: (Constant), Arus_Kas_X2, Penggunaan_Laba_X1 } \\
\text { b. Dependent Variable: Kinerja_Keuangan_Y }\end{array}$} \\
\hline Source & & sed by $\mathrm{S}$ & $2 \overline{5}(2021)$ & & \\
\hline
\end{tabular}

Based on table 4.5 , it can be seen that the adjusted $\mathrm{R}$ square value is 0.243 or $24.3 \%$. This shows that the Profit Usage variable (X1), Cash Flow (X2) can explain the Financial Performance variable (Y) by $24.3 \%$, the remaining $75.7 \%(100 \%-24.3 \%)$ is explained by other variables in outside this research model. According to Asset growth as a percentage change in total assets from the end of the fiscal year from the previous calendar year, to the end of the current calendar year.

\subsection{Partial test (T)}

The t statistic test is also known as the individual significance test. This test shows how far the influence of the independent variable partially on the dependent variable. In this study, partial hypothesis testing was carried out on each independent variable as shown in Table 4.6 below:

\begin{tabular}{|c|c|c|c|c|c|c|c|c|}
\hline \multicolumn{9}{|c|}{$\begin{array}{c}\text { Table 4.6. t test (Partial) } \\
\text { Coefficients }^{a}\end{array}$} \\
\hline \multirow[b]{2}{*}{ Model } & & \multicolumn{2}{|c|}{ Unstandardized Coefficients } & \multirow{2}{*}{$\begin{array}{l}\text { Standardized } \\
\text { Coefficients } \\
\text { Beta } \\
\end{array}$} & \multirow[b]{2}{*}{$\mathrm{t}$} & \multirow[b]{2}{*}{ Sig. } & \multicolumn{2}{|c|}{ Collinearity Statistics } \\
\hline & & $\mathrm{B}$ & Std. Error & & & & Tolerance & VIF \\
\hline 1 & (Constant) & 25145339.942 & 383891574.354 & & .066 & .948 & & \\
\hline & Penggunaan_Laba_X1 & .330 & .099 & .584 & 3.332 & .003 & .849 & 1.178 \\
\hline & Arus_Kas_X2 & .131 & .147 & .155 & .886 & .383 & .849 & 1.178 \\
\hline
\end{tabular}

Dependent Variable: Kinerja_Keuangan_Y

Source: Data processed by SPSS 25 (2021)

a. From this description, it can be seen that tcount (3.332) > ttable (2.048), as well as the significance value of $0.003<0.05$, it can be concluded that the first hypothesis is accepted, meaning that the Profit Use variable (X1) has a positive and significant effect on the Financial Performance variable ( Y).

b. From this description it can be seen that tcount $(0.886)<$ ttable $(2.048)$, as well as the significance value of $0.383>0.05$, it can be concluded that the second hypothesis is rejected, meaning that the Cash Flow variable (X2) has no effect on Financial Performance (Y). 


\subsection{Simultan test $(\mathrm{F})$}

Multiple correlation analysis is used to determine the degree or strength ofthe relationship between all variables X to variable Y simultaneously (Sugiyono, 2014).

Table 4.7. Simultan test $(F)$

\begin{tabular}{|c|c|c|c|c|c|c|}
\hline \multirow[b]{2}{*}{ Model } & \multicolumn{6}{|c|}{ ANOVA $^{a}$} \\
\hline & & Sum of Squares & df & Mean Square & $\mathrm{F}$ & Sig. \\
\hline \multirow[t]{6}{*}{1} & \multirow[t]{2}{*}{ Regression } & 1147800411926000 & & 573900205963000 & 5.649 & $.009^{b}$ \\
\hline & & 0000.000 & & 0100.000 & & \\
\hline & \multirow[t]{2}{*}{ Residual } & 2743105080211147 & 27 & 101596484452264 & & \\
\hline & & 6000.000 & & 7300.000 & & \\
\hline & \multirow[t]{2}{*}{ Total } & 3890905492137148 & 29 & & & \\
\hline & & 0000.000 & & & & \\
\hline
\end{tabular}

a. Dependent Variable: Kinerja_Keuangan_Y

b. Predictors: (Constant), Arus_Kas_X2, Penggunaan_Laba_X1

Source: Data processed by SPSS 25 (2021)

The form of hypothesis testing based on statistics and curves can be described as follows:

a. The value of Ftable is 3.35. From the description it can be seen that Fcount (5.649) > Ftable (3.35), and a significance value of $0.009<0.05$, it can be concluded that the third hypothesis is accepted, meaning that the Profit Use Variable (X1), Variable Cash Flow (X2) has a significant effect simultaneously (simultaneously) on the Financial Performance Variable (Y).

\subsubsection{Hypothesis Development Results}

a. Hypothesis Testing the Effect of Profit Use Variables (X1) on Financial Performance Variables (Y).

From this description, it can be seen that tcount (3.332) > ttable (2.048), as well as the significance value of $0.003<0.05$, it can be concluded that the first hypothesis is accepted, meaning that the Profit Use variable (X1) has a positive and significant effect on the Financial Performance variable ( Y). In accordance with the theory of earnings management, financial statements are a reflection of the results of the company's activities in a certain period, therefore financial statements are used as a decisionmaking tool by various parties (internal and external). The management as the manager of the company has more information about the company than the shareholders so that information asymmetry occurs which allows management to practice accounting with a profit orientation, namely earnings management. So that it can improve the company's financial performance at a certain time but can mislead owners (shareholders) about the true value of the company.

b. Hypothesis Testing the Effect of Cash Flow Variables (X2) on Financial Performance Variables (Y).

From this description it can be seen that tcount $(0.886)<$ ttable $(2.048)$, as well as the significance value of $0.383>0.05$, it can be concluded that the second hypothesis is rejected, meaning that the Cash Flow variable (X2) has no effect on Financial Performance (Y). In accordance with the theory, cash flow analysis is mainly used as a measuring tool to evaluate the source and use of funds. Cash flow analysis provides insight into how a company obtains its financing and measures its resources. In the final analysis, the company's cash flow is fundamental as a basis for accounting measurements and as a basis for decision making for investors and creditors. The role 
of the cash flow statement in the context of short-term decision making is as a tool to identify danger signs regarding the company's financial situation. From the analysis of the cash flow statement, information is obtained regarding the sources and uses of cash as well as forecasting the sources and uses of cash in the future.

c. Profit Usage Variable (X1), Cash Flow Variable (X2), have a significant effect simultaneously (simultaneously) on Financial Performance Variable (Y).

Sintije Rondonuwu (2017) "Analysis of Cash Flow Statements as a Measuring Tool for Financial Performance in Consumer Goods Industry Companies on the Indonesia Stock Exchange" From the results of the cash flow statement ratio analysis that has been carried out, the following are the conclusions of the performance results of Consumer Goods Industry Companies on the Indonesia Stock Exchange during a period of 4 years, namely from 2012-2015.

\section{CONCLUSION}

This study tries to answer the research objectives, namely to find out how the influence of Profit Usage, Cash Flow on the Financial Performance of private banking companies in Indonesia.

a. It can be concluded that the first hypothesis is accepted, meaning that the use of profit (X1) has a positive and significant effect on Financial Performance (Y). In other words, it means that the use of profit has a positive and significant effect on financial performance.

b. It can be concluded that the second hypothesis is rejected, meaning that Cash Flow (X2) has no effect on Financial Performance (Y). In other words, it means, Cash Flow has no positive and significant effect on Financial Performance.

c. It can be concluded that the fourth hypothesis is accepted, meaning that the Profit Use Variable (X1), Cash Flow Variable (X2), has a significant effect simultaneously (simultaneously) on the Financial Performance Variable (Y).

\section{SUGGESTIONS AND ACKNOWLEDGMENTS}

It is recommended for further researchers to expand the scope of the object of research so that later the results of this study can contribute thoughts, information and considerations to private banks in determining policies, on the use of cash flows so that companies are able to improve financial performance.

Thank you very much to the entire CV team. Express Consulting who has been able to carry out our dreams to create our own journal publishing. And thanks to our boss Dr. Rico Nur Ilham, S.E, M.M, RSA, CPRM as the owner of CV.Express Consulting who has facilitated the process in publishing this scientific article and also especially to the journal manager at CV. Radja Publika who is willing to cooperate in the process of publishing articles on Financial Performance. I personally Maulana Majied Sumatrani Saragih, S.E, M.M, CPRM would like to say a thousand thanks to all the teams who work at CV. Radja Publika.

\section{DAFTAR PUSTAKA}

Agung, G. 2012. Analisis Rasio Keuangan untuk Menilai Kinerja Keuangan PT Fajar Surya Wisesa Tbk Periode Tahun 2009, 2010 dan 2011. Fakultas Ekonomi Universitas Negeri Yogyakarta. Skripsi dipublikasikan. 
Agus Harjito dan Martono. 2012. Manajemen Keuangan. Edisi ke-2. Ekonisia, Yogyakarta.

Fahmi, Irham. 2015. Pengantar Manajemen Keuangan Teori dan Soal Jawab. Bandung: Alfabeta.

Fuadi, A. F. H. H., Ilham, R. N., \& Saputra, J. Investigating the Effect of Micro Waqf Bank Sector Expansion on Poverty Alleviation: An Evidence from Indonesia Rural Communities.

Ghozali, Imam. 2016. Aplikasi Analisis Multivariete Dengan Program IBM SPSS 23 (Edisi 8). Cetakan ke VIII. Semarang : Badan Penerbit Universitas Diponegoro.

Harahap, Sofyan Syafri. 2011. Analisis Kritis atas laporan Keuangan. Edisi PertamCetakan ke sepuluh. Jakarta : PT Bumi Aksara.

Ilham, R. N., Sinaga, S., Putri, D. E., Sinta, I., \& Fuadi, F. (2021). EFEK DARI LEVERAGE DAN UKURAN PERUSAHAAN DALAM MEMENGARUHI TINGKAT PROFITABILITAS. JURNAL ILMIAH EDUNOMIKA, 5(2).

Ilham, R. N., Sinurat, M., Saputra, J., \& Putri, D. E. Does Social media affect Banking Industry Financial Performance in Indonesia.

Ikatan Akuntan Indonesia. 2013. Standar Akuntansi Keuangan Entitas Tanpa Akuntabilitas Publik (SAK ETAP). Jakarta: Ikatan Akuntan Indonesia.

Kusumawardani, Media. 2012. Pengaruh Size, Kemakmuran, Ukuran Legislatif, Leverage Terhadap Kinerja Keuangan Pemerintah Daerah di Indonesia. Accounting Analysis Journal, Vol. 1. ISSN: 2252-6765.

ST. Maryam, Rachma Atamimi, Eko Sumartono, Dwi Orbaningsih, Riinawati (2020) GLOBAL FINANCIAL CRISIS MANAGEMENT BY HUMAN RESOURCE MANAGEMENT. Journal of Critical Reviews, 7 (1), 287-290. doi:10.31838/jcr.07.01.53

Munawir, S. 2012. Analisis Informasi Keuangan, Liberty, Yogyakarta.

Samryn, L.M., 2012, Akuntansi Manajemen Informasi Biaya untuk Mengendalikan Aktivitas Operasi dan Investasi. Edisi Pertama. Jakarta: Kencana Prenada Media Group.

Subramanyam, K. R. dan John J. Wild. 2014. Analisis Laporan Keuangan. Edisi 10. Buku Dua. Yang Dialihbahasakan oleh Dewi Yanti. Jakarta: Salemba Empat.

Sugiyono. (2014). Metode Penelitian Pendidikan Pendekatan Kuantitatif, Kualitatif, dan R\&D. Bandung: Alfabeta. 